\title{
Integrative Tourism Policy Development Based on Agro-Tourism In The City of Batu Malang East Java Indonesia
}

\author{
Tri Sulistyaningsih \\ Universitas Muhammadiyah Malang \\ Malang, Indonesia \\ Sulis226@gmail.com \\ Purnawan D. Negara \\ Universitas Widyagama Malang \\ Malang, Indonesia
}

\author{
Jainuri \\ Universitas Widyagama Malang \\ Malang, Indonesia \\ Hevi Kurnia Hardini \\ Universitas Muhammadiyah Malang \\ Malang. Indoensia \\ Suwarta \\ Universitas Widyagama Malang \\ Malang, Indonesia
}

\begin{abstract}
This research investigates the implementation of integrative tourism policy base on agro-tourism and fungtion in strengthening of tourism stakeholder in City of Batu Malang East Java Indonesia. Integrative policies in the development of tourism is a very important variable in the development of a city. Development program of the tourism sector, based on the Medium Term Development Plan (RPJMD) 2012-2017 Batu, Batu directed as a center for international tourism based organic farming. Location of Batu located in the mountainous region, making it very feasible as agro tourist area.The results of this study, found that the development of agro-tourism visitors increased more than $300 \%$ on 2016. However, this increase was not accompanied by the maintenance of conservation land. Implementation of tourism development are still partial and less integrated among sectors. This research question is how the local government response to the integrative policies in the development of agro-tourism sector in the city. How local governments understood and implemented an integrated policy in the development of agro-tourism sector. The research focus in Batu City in East Java Indonesia. The research method used in this study is a qualitative method. The data collecting through observation, depth interview, Focus Group Discussion (FGD), and the use of secondary data. The conclusion of this study is that regulation, peasant, peasant community, content of regulation, and integrity affect the responsiveness of local government in the development of based on agro-tourism. Integrative policy can be effective with the engagement between the government sector, policy content, policy instruments, and community participation.
\end{abstract}

Keywords-Policy, conservation, agro-tourism, farming areas, tourist institutions.

\section{INTRODUCTION}

The development of agro-tourism is a very important thing, especially for areas that have agro tourism potential, such as Kota Batu East Java. The vision of the City of Batu: "The City of Batu as Sentra Organic Agriculture Based on international tourism.The area developed as an agro tourism area is Bumiaji District. Bumiaji District determination as the development of agro tourism area based on the area of Bumiaji sub-district is $12,798.42 \mathrm{Ha}$ or $64 \%$ of the total Batu City area is $19,908,72$ ha. In the implementation of agro-tourism development in Bumiaji District of Batu City has not been able to run optimally. The development program of tourism sector in Batu City based on Medium Term Development Plan (RPJMD) 20122017. Problems of tourism sector development in Batu City are: 1) Implementation of policy and tourism program are not integrated by stakeholders; 2) The potential of a tourist attraction has not been properly managed; and 3) lack of understanding and citizen participation on agro tourism potential.

Integrative policy of tourism to develop the potential of agro-tourism. This study analyzing the profile of stakeholders, the government and the farmers and community activities of farmers, especially farmers community of guava, oranges, and krisan flowers. Investigation of these profiles and activities, it is expected to find understanding and behavior of farmers community about agro tourism. The problem solving offered in this research is to strengthen the farming community to develop farming business that is directed to the development of tourism base on agro-tourism. The method used 1) Optimization of agro tourism object; 2) Development of conservation alignment with agro tourism; 3) Community empowerment around the forest. Community empowerment through community approach and awareness is needed so that they can use and have access control in developing 
tourist village. Tourism activities utilizing local resources are developed based on sustainable economic goals, supporting environmental conservation efforts, and improving the welfare of local communities (Fandeli, 2001).

Based on government policy No. 7/2011 about spatial plans for the City of Batu planning 2010-2030, was decided that the municipalities (BWK) III as the main agropolitan area development, the development of tourism nature and environmental and agrowisata with the scope of Bumiaji to the center in the village punten service. This research investigates the implementation of integrative tourism policy base on agro-tourism and fungtion in strengthening of tourism stakeholder in City of Batu Malang East Java Indonesia. What is the current model of implementation integrative tourism policy in City of Batu Malang East Java Indonesia? What are the challenges to the stakeholders tourism in City of Batu Malang East Java Indonesia as local government agencies in using integrative tourism policy and its contribution to development of agro-tourism?

\section{Theoretical Framework \\ Tourism policy development}

Tourism policy generally viewed as part of the economic policy of .The economic policy of deals with the structure and economic growth usually manifested in the planning of the tourism. Several factors a key that come to the attention of the economic policy of 11 employment for example, investment and financial, industry, and trade ( gee , 2000: 28 ). Further gee ( 2000: 28 ) explained that formulations tourism policy is the responsibility of the main steps that should be undertaken by governments who willing to develop or maintain tourism as the parts which integral in the economy. Gee ( 1997: 286 ) more explicit policy explained generally referred to a plan to , a whole to a level that includes the purpose and procedures .For that public policy, take into account the results of a desired end of the government and other methods to achieve these results.

According to Wiendu (1993), tourist village is a form of integration between attractions, accommodation and supporting facilities presented in a community life structure that integrates with the prevailing rules and traditions. Tourist village usually has a tendency of rural areas that have uniqueness and attractiveness as a tourist destination. Village tourism is seen as a form of tourism industry in the form of activities to actualize identical trips include a number of activities that are appealing, seduce, encourage tourists as consumers to use the product of the tourist village or to travel to the tourist village or called village tourism marketing. The components of tourism products themselves consist of tourist transport, tourist attractions, and tourism accommodation (Soekadijo, 2000).

\section{Integrative Policy}

Experts public administration as henry ( 1989 ), and nigro and nigro ( 1980 ) have placed the importance of good in public policy formulation and the implementation of ( islamy , 2004 ). Public policy is not in a vacuum condition, Public policy influenced by various variable, social, political , economic, and culture. For that required integrative policy. The public sector has many roles to play in the co-ordination, planning, legislation and regulation, and financing of tourism, for the political, economic and social wellbeing of the nation as a whole. (Vanessa A. Amoah and Tom Baum, 1997)

Collaboration on policy formulation between the public and private sectors is expected. The opposite will give rise to poor quality of the tourism product or the host community's environment and way of lifeHence, sustainability itself is at risk. Public policies on tourism are responsible for planning, development and promotion, while tourism marketing is responsible for attracting tourists to a destination, develop goods and services to meet their needs and also is responsible for promoting the resources of a destination (Kotler, et. al 2008).

\section{Tourism Destination}

Tourists perceive the destination as a brand that includes a variety of suppliers and services. Before a visit, tourists develop an image about the destination, as well as a set of expectations based on previous experiences, word of mouth advertising, ads, etc. (Buhalis, 2000, citing Chon, 1991,1992). Ryan (1991) explains that companies and governments have implemented only a part of the marketing mix for tourism (promotion), with little attention to the other components of marketing. However, if tourism is to survive for tourists satisfaction, destinations should adopt social marketing strategies: this involves monitoring carefully the levels of tourists satisfaction and use them as part of the criteria for success, and be aware that the development of tourist infrastructure has implications for different market targets.

Tourism marketing should operate as a mechanism to facilitate regional development goals and streamline the provision of resources to tourism activities in order to ensure that a destination's strategic objectives are accomplished, and should also generate income according to the resources used for the production and development of tourism goods and the regeneration of these resources. Thus, the benefits will impact everyone involved in the tourism sector. (Martínez, Galván, and Lafuente, 2014)

\section{Agro-tourism Strategy}

Regionalization is a critical strategy for developing an agritourism experience, drawing on the "power of clusters of interesting sites, activities, and events that can only be accomplished on a regional basis through cooperation." The customers of this type of tourism, who usually travel with their family, tend to be educated and of predominantly urban origin (Hall and Jenkins 1998).

Agrotourism is more than just another tourist product, it goes well beyond a mere offer of services in a rural setting (Busby and Rendle 2000). Rather, it implies a novel 
way of understanding travel, a new awareness, a positive attitude towards other worlds, towards the environment and towards local people and their culture.

Cooperation and coordination between various stakeholders related in commercial operation agrowsisata very important and become a key factor in the development of success agro-tourism. . Cooperation and coordination between various stakeholders can vary, ranging from information until the form of cooperation with the legal and formal. Acreage of cooperation while also very broad covering all agrowisata the process of development, ranging from planning as determine the location of the area, including the implementation of the operational activities came to monitoring activities so that targets can be achieved in a sustainable way by giving great benefits for the local community in particular, as the concept of the development of its agro-tourism.

\section{Research Method}

The study of the research is composed by the cities of Batu Jawa Timur Indonesia. There are two (2) village used as an object of research, Punten and Sumber Brantas, both of which included in territorial Bumiaji Distric of Batu. This research was determined integrative tourism policy development based on agro-tourism. The research subjects were defined as follows the stakeholder of tourism, which composed of Municipalities of Batu and of farmers community, KPPDAS, Lancar Jaya, Melati and Non governmental Organization, Pusaka. The instrument used for this research is qualitative method, with indepth interview, Focus Group Discussion, and the use of secondary data. An analyzer used in this research was qualitative analysis interactive. This was initiated of data collection, organizing data, exposure to data, and the conclusion. Through the method of analysis it can be found a tendency to the projected integration policy integration or disintegration.

\section{Research Result}

The program included in the medium term development plan (RPJMD) Natu Cty.The vision of rock is years 2012-2017. city centre of organic agriculture kepariwasataan international based. The development program of tourism sector in Batu City based on Medium Term Development Plan (RPJMD) 2012-2017. Problems of tourism sector development in Batu City are: 1) Implementation of policy and tourism program are not integrated by stakeholders; 2) The potential of a tourist attraction has not been properly managed; and 3) lack of understanding and citizen participation on agro tourism potential.

Agro-tourim aims to accelerate the local economy (figure 1). Target is developing the agro-tourim empowerment investors agribusiness, main industries agricultural development, institutional development farmers and agricultural service providers, the development of conducive climate for farming and investment, and development of facilities and infrastructure supporting .In the development of developing the agropolitan , the act as investors and government officials act as facilitators ( Bappeda The East Java, 2011 ).

The agricultural sector is a sector which has unique and specific characteristic which in themselves of economic sectors. The sector is very much accommodate the overflow of labor, but in general the agricultural sector in composing regional gross domestic product gdp ) ( is not worth the trade sector hotel and restaurant .In 2000 the agricultural sector contributed value worth 22,36 grdp $\%$ and in 2010 fell to $20,64 \%$ while the tertiary sector, communication ) as much as 65,95 percent in the year 2000 and 68,67\% in 2010 ( BPS City of Batu , 2011)

The policy direction in the implementation of the mission is among others as follows: 1 .The development of tourism industry based the local culture and agrowisata , 2 .Tourism promotion of the regions and the reinvigoration of city branding rock is a tourism city at national and 
international levels .3 .Strengthen cooperation the tourism sector between the regions within the province and outside the province to an increase in regional economy, 4 .Improve its human resources tourism competent and professional.

The present in the sub district of Bumiaji position of kecamatan bumiaji is in the north of stone .On the north side is the district mojokerto, the south side in stone, the west in pujon unfortunate and eastern district junrejo .At first, in bumiaji is one area broken down in 1998 to 3 (three) district, namely kecamatan stone, in bumiaji and kecamatan junrejo .Third the area be part of administrative city rock in 2002 official stand alone and separate from Malang district.

Bumiaji Distric having forest of $8.751,60$ ha or 68,38 $\%$ of area has an important role as the supporting areas and source of absorption springs that is there Batu, that not only used by the people of stone but also regional other areas in the stream das brantas. That it is certainly development in the city Batu have to focusing on the principles of the sustainability of by integrating of three pillars a main element sustainable development that is economic, social and environmental and of course infrastructure as supporting third address these elements in the development of the area.

\section{Discussion}

The basic acknowledgement of tourism's importance along with other quality of life factors is often not present, thus their importance is minimized in the rural mindset. However, rural communities should develop active municipal and county park boards that are willing to collaborate with other tourism development agencies to enhance the local/state economy through sustainable tourism that achieves economic benefits. Agritourism enterprises offer a wide range of benefits to tourists, such as convenient, secure, educational, and amusing family experiences for visitors who are international, national, and Midwestern residents.

Thus, the agrarian sector is not only a provider of material goods, but also of immaterial goods, especially those connected with culture, education, gastronomy, landscape and the environment. A whole host of innovative activities related to the service economy have arisen, with a consequent boost to new types of employment. (Eduardo Parra López ,Francisco Javier Calero García, 2006)

The tourism sector, tourism activities is one of the main activities that can contribute to the economic development of the community in Bumiaji District. Mountain bikes activities in Bumiaji Village. Living With People is a tourism activity that aims to observe the pattern of life and participate in community activities in the apple farming sector. Living with people tourism activities are developed in Punten Village. The growing number of tangerines in Punten Village is expected by the village government to become a separate tourism icon for Punten Village. Punten Village, located in the city of mountain tourism is an advantage and a boon for Punten Village residents. Therefore, the village government is now developing the tourism potential in one of the hamlets, namely Dusun Kungkuk. There, is being pioneered the concept of a tourist village equipped with tourist facilities such as outbound, home-stay

The development of tourist village tourism village is seen as a form of tourism industry in the form of activities to actualize identical tourist trips include a number of activities that are appealing, seduce, encourage tourists as consumers to use the product of the tourist village or to travel to the village tour or called village tourism marketing. The components of tourism products themselves consist of tourist transport, tourist attractions, and tourism accommodation (Soekadijo, 2000). According Suswantoro (2007) in essence understanding of tourism products is the overall service obtained and perceived or enjoyed by tourists since he left his residence to the tourist destination until back home where he departed originally. The definition of tourism village products is thus very wide scope, including agro tourism. However, based on observations in Punten Village and Sumber Brantas Village, detect the phenomenon that they are less developed the potential of agro tourism owned. The existing agricultural potential is only managed conventionally by subsistence farmers' families or agricultural produce in selling out but very limited.

Environmental conservation.The development of agrowisata is expected to have the values of the environmental conservation. With a number of the trees, in addition to able to absorb noise, menjerap dust, curb the rain water, also able to raise fresh air and comfortable. The existence of the trees will be having the function of hydrological to hold water reserves .In addition, maintenance of various kinds of plant useful to preserve a source of germ plasm of cultivated plants .Essentially humans are so had a role on changes in its environment .Humans can make the environment for good and it could also change the environment for the worse .Soil fertility subject to change, a lot of the cause of the problem .One of the reasons in a reduction in fertility the ground he was kind the occurrence of erosion or pengikisan a layer of the surface of the ground .By the presence of this erosion soil layer that fertile will implement a current of water .Finally, the ground was bereft of nutrients necessary herbs. Underwent, land a desolate waste .

Agrowisata created, that more attractive for pengunjungnya, are not just to offer to visitors scenery flowers of beautiful or to enjoy stringed just fruit, but also received information about nursery, cultivation, until maintenance plants.So will they be on a nursery, visitors besides obtains pleasure can see beauty like flowers, color iridescent can also following the course lightning on the details of the je nis an ornamental.So that the visitors can 169 will picked a lot of benefits, for those who creative, may be able to develop similar business in the region.Management and improving the quality place agrowisata can collected in collaboration with the 
institutions pe nelitian or education.The form of cooperation that it will be useful for both sides.The management agrowisata providing a place and sarah na research, while scientists could penyumbangkan her research for science development.

\section{Conclusion}

The results of devotion the study was focused on the development of tourism model based tourism agro .Second, this study are trying to figure how the profile and behavior farming community in understanding agro tourism .This study to conclude that the rise of the less able to tour agro , triggered by the lack of understanding farmers and farming community one was about agricultural potential possessed to be developed at agro tourism .A way of seeing the farmers who konvensial and perfikir and behave substantive enough be a hindrance the development of tourism potential agro .On the other hand there are a group that quite unaware of the importance of tourism for the improvement of agro tourist destination and in turn will enhance the welfare of the community, namely those who are joined in a group tour conscious ( pokdarwis ), but this group have not yet be run well .He has only work well if there is a particular activity, not yet sustainable

On the other hand, the government and all regulations or his policy not menyentuk owned up to the residents in massif .The approach used still deeply teknokratik and top down, as a result the less able terimplementasikan well .On top of that, in the perspective of a government less emphasis on tourism model based on capital intensive and less local potential, has influenced terpinggirkannya tourism agro .Based on observations, interview, and with related to the development of wisato agro, this study is building the integrative / theory governmental-comminity ( gci ) model .Model is based on the mind sherry arnstein ( ) 1971 .Gci model , doing construction on the concept of eight households arnstein sharry participation .If in arnsten households participation as separate from the object of the policy makers, while gci model is harmony between residents and the government .Democratic egalite suassana

Governmental-comminity integrative ( gci ) model, describing unsur-unsur or instrument which is input into integrative policy, the farmers, farming community, mentor and ngos.Intrumen such as then diaolah in the process of integrative policy.Besides inetgrative policy have also noticed potential underlying, namely the potential tourism objects.In turn would be tourism objects that can be measured of the means / infrastructure, agricultural production, culture tourism objects, and tourist attractions agro.Plans the coming year, 2017 will be conducted dig deeper to conduct the community and behavior pemeintah in implementing a policy for developing tourism objects.In addition to be tried out model governmental-comminity integrative ( gci ), to examine and in order to get inputs to improve the model, and desiminasi model.

\section{Acknowledgement}

The authors are cordially to thank to to directorate general of higher education that have financed devotion this, university leaders, leader and all staff of the directorate of research and devotion ( dppm ) umm, stakeholders, municipal stone, environment agency, and partner this devotion. Hopefully devotion was beneficial for scientific development and the sustainability of development based tourism conservation and agrowisata.

\section{Reference}

[1] Bappeda Provinsi Jawa Timur, 2011. Pedoman Umum Pengembangan Kawasan Agropolitan Provinsi Jawa Timur Tahun 2011. 43p.

[2] Buhalis, D. (2000). Marketing the competitive destination of the future. Tourism Management 21, 97-116.

[3] Eduardo Parra López , Francisco Javier Calero García (2006), Agrotourism, sustainable tourism and Ultraperipheral areas: The Case of Canary Islands. PASOS. Revista de Turismo y Patrimonio Cultural. ISSN 1695-7121

[4] Jie Gao, Carla Barbieri, and Corinne Valdivia, Agricultural Landscape Preferences: Implications for Agritourism Development, Journal of Travel Research2014, Vol. 53(3) 366-379

[5] Kotler, P., Bowen, J. y Makens, J. (2008). Marketing para Turismo. ( $3^{\mathrm{a}}$ ed.). España: Prentice Hall.

[6] Melissa Ramsey, Nathan A. Schaumleffel,(2006). Indiana University, Kelley School of Business, Indiana Business Research Center

[7] Poerbo, Hasan, 1999. Lingkungan Binaan Untuk Rakyat, Penerbit Yayasan Akatiga, Bandung.

[8] Ryan, C. (1991). Tourism and marketing-A symbiotic relationship. Tourism Management, 12(2), 101-111.

[9] Rubén Molina Martínez, Melissa Ochoa Galván ,Ana María Gil Lafuente, Public Policies and Tourism Marketing. An analysis of the competitiveness on tourism in Morelia, Mexico and Alcala de Henares, Spain. Procedia - Social and Behavioral Sciences 148 (2014) $146-152$

[10]Sastrayuda , Gumelar S. (2011) Hand Out Mata Kuliah Concept Resort And Leisure.

[11]Vanessa A. Amoah,Tourism education: policy versus practice, International Journal of Contemporar y Hospitality Management 9/1 [1997] 5-12

[12] Vianda Kushardianti Muzha, Heru Ribawanto, Minto Hadi. PENGEMBANGAN AGROWISATA DENGAN PENDEKATAN COMMUNITY BASED TOURISM (Studi pada Dinas Pariwisata Kota Batu dan Kusuma Agrowisata Batu). Jurnal Administrasi Publik (JAP), Vol 1, No.3, hal. 135-141

[13] Wang D, Ap J. Factors affecting tourism policy implementation: A conceptual framework and a case study in China. Tourism Management, vol. 36 (2013) pp. 221-233

[14] Yeremia Azarya Dimpudus, Ir. Chairil B Amiuza, MSA, Ir. Ali Soekirno. Penataan ruang terbuka kawasan agrowisata Petik buah kota batu berdasarkan aspek Aspek Kenyamanan pengunjung Jurusan Teknik Arsitektur, Fakultas Teknik, Universitas Brawijaya 